\title{
Ideology, Hegemony, Discourse: A CRItical Review of TheORIES OF KnOwledge ANd Power
}

\author{
MARK C. J. STODDART \\ University of British Columbia
}

For over a century, social theorists have attempted to explain why those who lack economic power consent to hierarchies of social and political power. They have used ideology, hegemony and discourse as key concepts to explain the intersections between the social production of knowledge and the perpetuation of power relations. The Marxist concept of ideology describes how the dominant ideas within a given society reflect the interests of a ruling economic class. In this paper, I trace the movement from this concept of ideology to models of hegemony and discourse. I then trace a second set of ruptures in theories of ideology, hegemony and discourse. Marx and others link ideology to a vision of society dominated by economic class as a field of social power. However, theorists of gender and "race" have questioned the place of class as the locus of power. I conclude by arguing that key theorists of gender and "race"-Hall, Smith, hooks and Haraway-offer a more complex understanding of how our consent to networks of power is produced within contemporary capitalist societies. This argument has important implications for theory and practice directed at destabilizing our consent to power.

Mark C.J. Stoddart is a $\mathrm{PhD}$ candidate in the Department of Sociology at the University of British Columbia, in Vancouver, Canada. His ongoing research examines how skiing, as a form of recreational land use, relates to environmental politics and the social meaning of the British Columbia landscape. Mr. Stoddart holds a doctoral fellowship from the Social Sciences and Humanities Research Council of Canada (SSHRC). E-mail: mcjs@interchange.ubc.ca. Phone: (250) 226-6843. The author wishes to thank Dr. Thomas Kemple, Dr. Dawn Currie, Dr. Renisa Mawani and Justin Page for their comments during the development of this paper as well as the anonymous reviewers for their comments. 


\section{Introduction}

For over a century, social theorists have attempted to explain why those who lack economic power consent to hierarchies of social power that privilege some while exploiting others. Theories of ideology, hegemony and discourse have been used to explain the intersections between the social production of knowledge and the perpetuation of inequitable power relations. These bodies of theory attempt to link an understanding of social privilege and injustice with an account of the production and circulation of culture and knowledge. Here, the social production and dissemination of knowledge secures our consent to systematic social inequity.

The key concept of ideology is the starting point for this theoretical overview. Marxist theory uses the notion of ideology to describe the process through which the dominant ideas within a given society reflect the interests of a ruling economic class. However, ideology has proven a problematic notion, as many of its proponents have treated it as a relatively stable body of knowledge that the ruling class transmits wholesale to its subordinate classes.

In his article, "Cultural Studies and its Theoretical Legacies," Stuart Hall (1992) reviews several moments of theoretical "interruption" in cultural theories of ideology (p. 282). These include the discourse theories of post-structuralism and postmodernism, on one hand; and the impact of feminist and critical "race" scholarship, on the other. ${ }^{1}$ The interruption of post-structuralism is important for foregrounding the salience of language as a medium of social power. By contrast, feminist theory contributes a notion of the personal dimensions of political power and emphasizes questions about gender. Similarly, critical "race" theory focuses on racialized patterns of power and destabilizes the class subject of ideology theory.

\footnotetext{
${ }^{1}$ Throughout this paper, I use the word "race" in quotation marks to emphasize the social construction of race through discourses of racialization. The quotation marks assert distance from a notion of race as a reified, biological social category. That is, "race" refers to the products of racializing discourse that may be taken up by individual and collective actors at specific social-historical locations. I retain the term "race" to acknowledge the continuing salience of the term in public discourse.
} 
I will take Hall's brief discussion of these theoretical interruptions as an inspiration and point of departure for the present paper.

Less a point of rupture than a radical reinterpretation of Marxist ideology theory, Antonio Gramsci uses the concept of hegemony to illustrate how the state and civil society produce and maintain consent to the class hierarchies of capitalist society (Hall 1992; Hall 1996b). Whereas ideology connotes closure and a unidirectional flow of power, hegemony emphasizes the inherent conflict involved in constructing networks of power through knowledge. With the concept of discourse, post-structuralism and post-Marxism further challenge the notion of ideology. Discourse theory argues against the economism of ideology theory and undermines the privileged standpoint of the working class as a historical actor. Here, social power is diffused among a gigantic web that lacks a definite center.

In this paper, I trace the movement from ideology to hegemony and discourse. Through a selective review of key theorists, I illuminate the points of tension and continuity between these perspectives. However, these approaches are not mutually contradictory options for understanding social power. Rather, we might usefully locate them along a continuum. This continuum allows us to visualize the ongoing tension between critical theory's attention to political praxis, oppression and domination, on one hand; and post-structuralism's attention to complexity, fragmentation and the microstructures of power, on the other. While theories of discourse emerge prior to ideology theory, in a temporal sense, the continuum allows us to visualize the continuity between these concepts. In other words, theories of discourse rarely act as a total negation of the notion of ideology. Instead, discourse, hegemony and ideology are intertwined with each other. For example, while Purvis and Hunt (1993) argue that while we can analytically separate discourse and ideology, we should also understand ideology as an effect of discourse. In essence, where discourse is mobilized to reinforce systems of social power it functions as ideology. For these authors, discourse is not necessarily ideological; however, ideology is discursive.

Insofar as I am interested in the points of tension and continuity between Marxist critical theory and post-structuralist theories of 
discourse, this theoretical overview fits into other work that address the ways that critical theory might engage with post-structuralism (Agger 1998; Best and Kellner 1991; Eagleton 1991). While I focus on how these bodies of theory conceptualize the relationship between the cultural production of knowledge and the reproduction of social power, I also wish to broaden the scope of discussion beyond offering ideas about a rapprochement between critical theory and post-structuralism. Thus, I will trace a second set of ruptures in theories of ideology, hegemony and discourse. Marx and others link their concept of ideology to a vision of society dominated by economic class as a field of social power. However, critical theories of gender and "race" have disrupted the Marxist model of ideology. By bringing attention to the production of gendered and racialized networks of social power, these bodies of work have decentered class as the locus of power.

Finally, I offer Figure 1 as a theoretical map, which overlays these two theoretical movements and which illustrates the scope of this theoretical overview. First, there is a movement from ideology towards discourse. Second, there is expansion away from class as the most salient political subject position, towards a greater focus on gender and racialization as important mechanisms of structuring social life (see Figure 1). I will proceed to trace a route through this theoretical map as follows. First, I will examine critical theories of ideology, beginning with Marx and ending with Gramsci. Second, I will review post-structuralist and post-Marxist approaches to discourse. These bodies of work constitute important moments of rupture in theories of ideology.

The following two sections of the paper will examine critical theories of gender and "race," which represent two further points of rupture. Here, the main impact is the decentering of class as the central dimension of social power and political action. I will conclude by arguing that theorists working in these latter areas-including Dorothy Smith, Stuart Hall, bell hooks and Donna Haraway_ offer the most complex and promising understanding of how consent to social power is produced. This argument has important implications for theory and practice directed at destabilizing our consent to power, which I will draw out in the concluding section of the paper. 
Figure 1: Mapping Theories of Ideology and Discourse

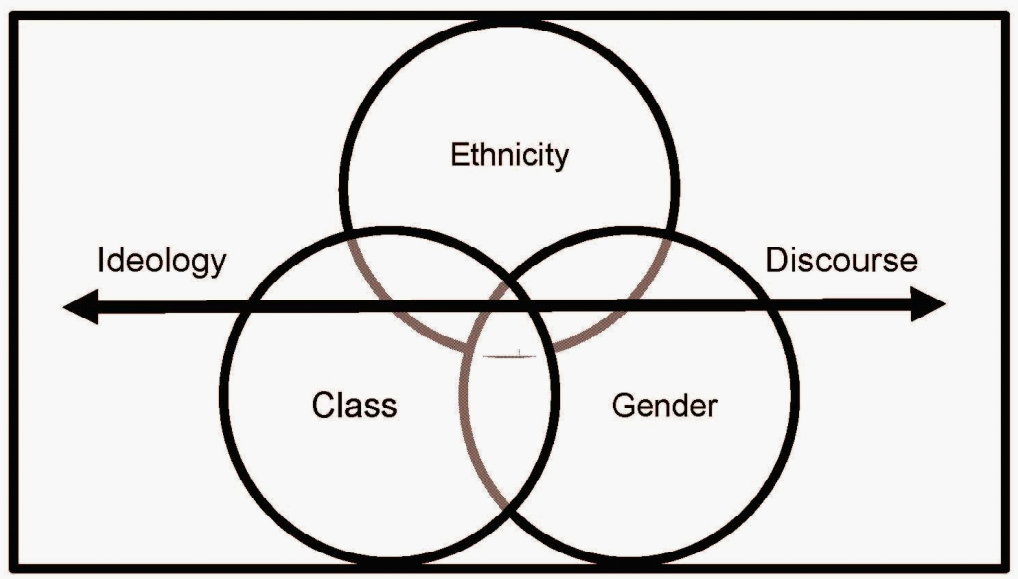

\section{Critical Theories of Ideology}

An Origin Story: Marx's Notion of Ideology

The notion of ideology, as it informed critical social theory throughout the twentieth century, emerged in the work of Karl Marx (1977; also see Marx and Engels 1989). Here, ideology refers to the ways in which society as a whole adopts the ideas and interests of the dominant economic class. Marx's model of ideology rests upon a historical-materialist perspective, which asserts that material reality is the foundation of social consciousness. Material reality sets boundaries on the ideas that may emerge as important, or even acceptable, in a given social setting. However, it is through the dominant ideologies of capitalism that the working classes take for granted their exploitation within economic structures of inequality.

For Marx, the most important aspects of material reality centre on human productive labor. The appropriation of resources from the natural world for the production of goods is the foundation of social life. Within a capitalist mode of production, the most important social relations are those between members of the working class as they engage in productive labor, as well as the relations between the working class and the capitalist class, which owns the means of production (such as factories and machines). Through their owner- 
ship of the means of production, the capitalist class gains the power to appropriate the labor of the working classes, who lack access to the means to produce the necessities of survival - including food, clothing, shelter - for themselves.

Ideology enters Marx's theoretical framework to explain how the subordinate classes take exploitative relations of production for granted, as something solid and unchangeable. One way in which this is accomplished is the way in which objects with use value become commodities characterized by their exchange value. Objects produced through human labor have value insofar as they fulfill a particular function. The use value of wood may be realized if I build a house; the use value of an apple is realized when I eat it. By contrast, exchange value refers to the social labor that is required to produce the same objects for a capitalist economy.

The move from use value towards a system of exchange value removes from visibility the role of human labor in producing value. Commodity "fetishism" refers to the way in which the objects produced by human labor are divorced from that productive labor and are re-located in the economy of exchange value within a capitalist mode of production (Marx 1977:165). This process is ideological in the sense that it obscures the central importance of labor to social life. It transforms the material product of human labor into a "social hieroglyphic" which is undecipherable to capital's subordinate classes (p. 167). Through this process, elite social groups naturalize capitalist relations of production. Workers come to view the capitalist mode of production as the only viable option, where they must sell their labor power to the capitalist class in order to obtain commodities. Ideology, then, functions to secure the participation of subordinate classes in exploitative relations of production.

For Marx, the equation of labor power with money, or wages, is another way in which ruling groups secure the consent of the working classes for their own exploitation. Workers exchange their labor power for wages, which they use to purchase the commodities that they produce, but which the capitalist class owns and sells. This transmutation of labor into wages creates a false reality for workers. Marx writes: 
What flows back to the worker in the shape of wages is a portion of the product he himself continuously reproduces. ... The illusion created by the money form vanishes immediately if, instead of taking a single capitalist and a single worker, we take the whole capitalist class and the whole working class. The capitalist class is constantly giving to the working class drafts, in the form of money, on a portion of the product produced by the latter and appropriated by the former. The workers give these drafts back just as constantly to the capitalists ... The transaction is veiled by the commodity-form of the product and the money-form of the commodity (Marx 1977:712-713).

Marx's use of terms like "illusion" and "veiled" suggests that both the commodity form and money play an ideological role in securing the willing participation of the working classes in their own domination. Wages construct an illusion for the working class that veils the exploitative relation of the appropriation of surplus value.

In Marx's writing, resistance to ideology must take a primarily material form. It is not sufficient to analyze ideological systems from a theoretical or academic standpoint. He writes, "All forms and products of consciousness cannot be dissolved by mental criticism . . . but only by the practical overthrow of the actual social relations which gave rise to the idealistic humbug" (Marx and Engels 1989:258). Political praxis must involve people acting for social change within the mode of production. Just as material reality gives rise to the dominant ideologies of a society, people can only overcome the ideology of capitalism through action directed at transforming the economic substructure of society.

\section{The Frankfurt School and Ideology}

The Frankfurt School theorists, including Walter Benjamin, Max Horkheimer, Theodor Adorno and Herbert Marcuse, took up Marx's concept of ideology, expanded upon it and gave it greater depth. One of the central problematics in this body of work is the failure of the proletariat to transform the capitalist mode of production through revolutionary action, as predicted by earlier Marxists. As an explanation for the acquiescence of the proletariat, these 
theorists revisited the ideological superstructure as a primary site for securing the consent of the dominated classes to capitalist relations of production. Throughout the twentieth century, culture has become increasingly available to the working classes. As Walter Benjamin (1968 [1936]) notes, technological change has allowed the "mechanical reproduction" and mass dissemination of culture (p. 218). Cultural products, such as movies, music, radio broadcasts and books, now permeate the everyday lives of a greater proportion of the population.

However, this diffusion of culture throughout society represents a superficial democratization that is misleading. Horkheimer and Adorno (2002) describe a "culture industry" that is an ensemble of media forms (film, newspapers, radio) that transmits ideological representations of the world to the masses (p. 95). Echoing Marx, contemporary culture does ideological work by representing the capitalist mode of production as the only possible world, as something unchangeable. This ideological system depicts people as essentially the same, regardless of class position. In a similar vein, people come to perceive class mobility as a matter of luck. As such, there is no point in organizing to resist unequal relations of power. The culture industry is also a homogenizing force that renders people more alike, while promoting a false sense of individuality. Thus, people may feel unique through their distinct cultural tastes. However, the similar underlying ideological content of the culture industry, which incorporates everyone as consumers, is much more important than the superficial differences between cultural products.

Herbert Marcuse (1991 [1964]) offers a similar critique of the ideological dimensions of modern cultural production. In the "onedimensional" society of the twentieth century, capital incorporates the working classes into an ever-increasing standard of living. The expansion of scientific and technological rationality allows an ever-increasing number of people to overcome material scarcity. Through this process, elites secure the consent of subordinate groups to their unequal participation in capitalist relations of production. Where people can more easily meet their "true needs," their attention turns to the "false needs" that the capitalist classes construct 
(Marcuse 1991 [1964]:4). That is, where the working class is able to lead a relatively comfortable existence, it loses its revolutionary potential (p. 16). Instead, members of the working class willingly sell their labor in order to participate in a consumer society filled with unnecessary spectacle and widgets.

Marcuse further describes how the democratization of culture is one of the means by which the oppositional standpoint of the working class is submerged within taken-for-granted capitalist relations of production (p. 56). He writes:

Domination has its own aesthetics, and democratic domination has its democratic aesthetics. It is good that almost everyone can now have the fine arts at his [sic] fingertips, by just turning a knob on his set, or by just stepping into his drugstore. In this diffusion, however, they become cogs in a culture-machine which remakes their content (p. 65).

Again, we see the notion that a democratized mass culture effectively dissolves critical consciousness. For Marcuse, the result of this is the waning importance of Marx's working class as a historical actor. If there is to be a revolutionary rejection of capitalist relations of production, those who have not been integrated into the one-dimensional society offer the only real hope for such an "absolute refusal" (p. 255).

Mass culture is not the sole factor that explains why people accept capitalist social relations as inevitable. Horkheimer and Adorno (2002) argue that the increasing reach of scientific and technological rationality similarly makes us believe that the structures of the existing social world are unchangeable. As science and technology make human interactions with nature more predictable and controllable, anything that cannot be incorporated into scientific knowledge systems appears politically unrealistic. People understand social change as a matter of technological progress, not political will. The ideological function of scientific and technological rationality is further taken up by Marcuse (1991 [1964]). For him, science reduces non-human nature to "potential instrumentality, stuff of control and organization" (p. 153). This re-construction of nature into something predictable and controllable creates a one-dimen- 
sional lifestyle that the dominated classes become accustomed to and are reluctant to give up, even though this means accepting their own domination (p. 166). As Marcuse writes, "Nature, scientifically comprehended and mastered, reappears in the technical apparatus of production and destruction which sustains and improves the life of the individuals while subordinating them to the masters of the apparatus" (p. 166). Like the world of mass culture, the scientifictechnological world is a world of inevitable social inequality.

In general, the Frankfurt School theorists emphasize the cultural realm and the growth of scientific rationality as important sites of domination, where dominant classes exercise power through ideology. They provide a useful corrective to Marx's focus on economic production as the primary site of power, oppression and resistance. However, these theories tend to attribute a degree of homogeneity to the cultural sphere that is debatable. In this work, there is also a sense that ideological power flows in a relatively unidirectional manner from the capitalist class to mass audiences. There is little room here for audience agency, critique or resistance. Here, we get the impression of the theorist standing above the masses, seeing what the masses cannot because of a totalizing capitalist ideology.

\section{Gramscian Theory and Hegemony}

The concept of ideology, as used by Marx and the Frankfurt School theorists is productive insofar as it shows that social power operates throughout the cultural realm of society. Ideological systems work to integrate people into social networks of oppression and subordination. However, this model of ideology is limited in that it seems too unitary, too totalizing, and too abstracted from the everyday social interaction of individual actors. The theoretical work of Antonio Gramsci and his successors adds a great deal of complexity to the concept of ideology. While Gramsci builds upon the Marxist theoretical tradition, his notion of hegemony represents an important reinterpretation of the concept of ideology.

The notion of "hegemony" is rooted in Gramsci's (1992) distinction between coercion and consent as alternative mechanisms of social power (p. 137). Coercion refers to the State's capacity for 
violence, which it can use against those who refuse to participate in capitalist relations of production. By contrast, hegemonic power works to convince individuals and social classes to subscribe to the social values and norms of an inherently exploitative system. It is a form of social power that relies on voluntarism and participation, rather than the threat of punishment for disobedience. Hegemony appears as the "common sense" that guides our everyday, mundane understanding of the world. It is a view of the world that is "inherited from the past and uncritically absorbed" and which tends to reproduce a sort of social homeostasis, or "moral and political passivity" (Gramsci 1971:333). Whereas coercive power is the exclusive domain of the State, the institutions of "civil society," such as the Church, schools, the mass media, or the family, are largely responsible for producing and disseminating hegemonic power (Gramsci 1996:91). In industrial capitalist societies, hegemonic power is the prevalent form of social power; the state relies on coercion only in exceptional circumstances.

Like the Frankfurt School theorists, Gramsci ascribes a greater degree of importance to the cultural superstructure of capitalist societies than is attributed by Marx. From this perspective, the superstructure does not simply reflect the economic base. Rather, there is a meaningful degree of autonomy between the spheres. This means that the ideas of the ruling classes do not necessarily become the defining values of society as a whole. Rather, ongoing social action creates and reproduces hegemonic power. Hegemonic networks of power are the result of contestation between ruling elites and "subaltern" groups (p. 21). Because contestation is basic to the process of constituting hegemony, there is never a unified, totalizing system of ideological domination. Hegemony and counterhegemony exist in a state of tension; each gives shape to the other. For Gramsci one of the main issues facing dominant social groups is how to maintain the necessary degree of "ideological unity" to secure the consent of the governed (Gramsci 1971:328).

Gramsci also asserts that hegemony has a material dimension. It is not only a system of ideas, floating above economic structures. Rather, the social action of everyday life produces hegemonic effects. Writing about the emergence of Fordist production in the 
United States, for example, Gramsci (1992) describes an American hegemony that is "born in the factory" (p. 169). Gramsci (1996) describes how the interplay of our cultural and material surroundings constructs hegemony as follows:

The press is the most dynamic part of the ideological structure, but not the only one. Everything that directly or indirectly influences or could influence public opinion belongs to it: libraries, schools, associations and clubs of various kinds, even architecture, the layout of streets and their names (p. 53).

Furthermore, hegemony often lies beneath the surface, unarticulated. As Williams (1977) writes, "A lived hegemony is always a process. It is not, except analytically, a system or a structure. It is a realized complex of experiences, relationships, and activities, with specific and changing pressures and limits" (p. 112). This illustrates how hegemony works as a sort of common sense, rather than as a coherent body of thought, such as we would associate with ideology.

Gramsci gives us an image of society in which the cultural realm is a central location for the exercise of social power. By comparison with the Frankfurt School theorists, however, hegemonic power is something that is always contested, always historically contingent and always unfinished. He ascribes a high level of importance to the subaltern classes, intellectuals, and revolutionary political parties as agents for social change. For Gramsci, a revolutionary seizure of the means of production is not a viable tactic for creating radical social change in modern capitalist societies. Where a society is characterized primarily by the exercise of hegemonic power instead of coercion, a prolonged cultural "war of position" is more important, where the hegemony of the ruling classes is dissembled and a new hegemony is crystallized (Femia 1975: 34). This occurs as subaltern groups realize their own capacity to become philosophers of their daily experience; they come to understand the hegemonic common sense that they otherwise take for granted.

The Gramscian model of hegemony departs significantly from the Marxist notion of ideology, while retaining Marxist foundational categories of class, the capitalist mode of production, and the dis- 
tinction between the economic base and the cultural superstructure. Among the advances made by Gramscian theory is the attention to hegemonic power as an often-implicit "common sense" rather than a coherent body of thought, which is inherently unfinished and historically contingent. It is the embodiment of hegemony in everyday common sense, through the mundane activities connected with work, school, the family and the church, that secures the consent of capital's subaltern classes.

\section{The First Point of Rupture: Post-Structuralism and Post-Marxism}

While Gramscian theory begins the process of transforming the Marxist model of ideology, it remains grounded in a Marxist framework where class is the primary force that structures social action. Here, I will turn to theorists who make a more decisive break from the Marxist framework and posit the concept of discourse as an alternative to the Marxist notion of ideology.

\section{Post-structuralism: Foucault}

The concept of "discourse" has a central role in the work of Michel Foucault (1978). Discourses are systems of thought, or knowledge claims, which assume an existence independent of a particular speaker. We constantly draw upon pre-existing discourses as resources for social interactions with others. We may think of the discourses of academia, which we use to navigate our way through school; discourses of medicine, which are employed by doctors and patients in medical settings; or the discourses of wilderness that are evoked by environmental groups to argue for the preservation of parks. Our sense of self - our subjectivity - is constructed through our engagement with a multitude of discourses. In Foucault's work, this construction of subject positions shapes our acceptance of relations of unequal social power.

Foucault explicitly demarcates discourse from ideology. For him, the notion of ideology contains several problems (Foucault 1980a; Foucault 1980b; Foucault 2000 [1994]b). First, Marxist 
theory typically sees ideology as something fake, which stands in opposition to true knowledge. Foucault describes ideology thus:

In traditional Marxist analyses, ideology is a sort of negative element through which the fact is conveyed that the subject's relation to truth, or simply the knowledge relation, is clouded, obscured, violated by conditions of existence, social relations, or the political forms imposed on the subject of knowledge from the outside (Foucault 2000 [1994]b:15).

Instead, Foucault describes how "truth" is produced out of social relations and that political relations of power are "the very ground on which the subject, the domains of knowledge, and the relations with truth are formed" (p. 15). Second, social theorists have often treated ideology as an effect of economic structures. By contrast, Foucault wants to re-locate the production of "truth" in social relations, rather than in social structures.

Third, ideology seems to presuppose individual and collective subjects who are lulled into compliance by the false claims of the ruling classes. Writing explicitly against Marx, Foucault claims, "Labor is absolutely not man's [sic] concrete essence," an objective reality which is distorted by capitalist ideologies (Foucault 2000 [1994]b: 86). If we take labor as the thing that defines us as subjects, it is only because "a web of microscopic, capillary political power had to be established at the level of man's very existence, attaching men to the production apparatus" For Foucault, the creation of the laboring subject is not the natural outcome of changes in the mode of production. It is something that emerges from social processes; it is "synthetic, political; it was a linkage brought about by power" (p. 86). While ideology often takes a discursive form, the power effects of discourse are more subtle and complex than the model that suggested by Marxist theory.

One of the most important theoretical contributions made by Foucault is his re-thinking of the notion of power and his model of the relationship between power and knowledge. He views power not simply as coercive power, wielded like a weapon by the state and by capital. Rather, Foucault (1978; 2003; 2000 [1994]a) offers an alternative conceptualization of power, which has several 
characteristics. First, power is not only a macrosocial phenomenon. Rather, we must understand power as operating throughout a multiplicity of sites at a local level. Second, power is not only repressive; it is not only a tool of control wielded by one class, or set of social institutions, over subordinate classes. Rather, power flows in multiple directions. Wherever mechanisms of power are mobilized, there are also opportunities for resistance. Third, notions of a "Great Refusal," in the Marxist sense of a proletarian revolution, are untenable (Foucault 1978: 96). Just as power operates at essentially local sites, so do "points of resistance" appear "everywhere in the power network" (p. 95). This notion of resistance further emphasizes the essentially local nature of power. Taking these characteristics together, we may note that the most important aspect of power is that it is fundamentally relational. As Foucault notes, "If we speak of the power of laws, institutions, and ideologies, if we speak of structures or mechanisms of power, it is only insofar as we suppose that certain persons exercise power over others The term 'power' designates relationships between "partners" (Foucault 2000 [1994]a:337).

For Foucault, the production and circulation of discourses are simultaneously mechanisms of social power. Corollary to this, he asserts that those who wish to exercise social power must use discourse in order to do so. The regulation of discourse deals with who is allowed to speak on a given topic, as well as which forms of knowledge are subjugated in the production of truth. As Foucault (2003) notes, "The delicate mechanisms of power cannot function unless knowledge, or rather knowledge apparatuses, are formed, organized, and put into circulation, and those apparatuses are not ideological trimmings or edifices" (pp. 33-34). Similarly, we should be attentive to the silences that lie outside the boundaries of acceptable debate, for they are also part of the networks of power-knowledge that make up the discursive economy.

Finally, if discourses are sites for the exercise of social power, then the production of discourse may also constrain and challenge the exercise of power. Emphasizing the inherent capacity for resistance within power relations, Foucault writes, "The power relationship and freedom's refusal to submit cannot therefore be separated. ... At the very heart of the power relationship, and constantly 
provoking it, are the recalcitrance of the will and the intransigence of freedom" (Foucault 2000[1994]a: 342). Therefore, networks of power/knowledge are also sites of resistance, where all of the partners within a power relationship produce and contest the truth.

From Foucault, we see that discourse is an important object of social analysis, in and of itself. We also see that discourse operates in a more open, fluid and negotiated manner than models of ideology suggest. At the same time, critics of Foucault argue that he places too much emphasis on the discursive realm, while paying insufficient attention to the materiality of social actors who exist within economic relationships of social power (Hartsock 1990; Smith 1990; Smith 1999).

Turning to the question of why the subjects of unequal power relations submit to their position, we may infer from Foucault that an acceptance of social inequality is part of the process whereby we take up discourse and incorporate it into our sense of self - our subjectivities. Discourses of truth reinforce larger-scale patterns of inequity as they are "taken for granted" and "consolidated" by a multiplicity of individuals inhabiting a range of social sites (such as the hospitals, psychiatric hospitals and prisons investigated by Foucault through his own research trajectory).

\section{Post-Marxism: Laclau and Mouffe}

Ernesto Laclau and Chantal Mouffe (1985) offer a post-Marxist model of discourse that builds upon the Marxist problematic of relations of oppression and domination within capitalism. Drawing on a Gramscian framework, they are concerned with the ways in which social power and resistance function through discourse. In their model, hegemony is achieved through the discursive connection of subject positions within the social realm. They adopt a more open, fluid conception of hegemony than Gramsci, arguing that there are only hegemonic moments within a complex and shifting discursive social reality. They write:

Hegemony is, quite simply, a political type of relation, a form, if one so wishes, of politics; but not a determinable location within 
a topography of the social. In a given social formation, there can be a variety of hegemonic nodal points . . they may constitute points of condensation of a number of social relations ... insofar as the social is an infinitude not reducible to any underlying unitary principle, the mere idea of a centre of the social has no meaning at all (Laclau and Mouffe 1985:139).

Laclau and Mouffe focus on deconstructing the essentialist elements of critical theories of ideology. For example, they reject the notion of class as a foundational category of political identity. They argue that a sense of political identity does not emerge from one's class position. Rather, individuals work to construct a collective political identity through discourses that create relations of "equivalence" between subject positions (p. 128). There is no preordained reason why the working class should adopt a left politics. Discourses of equivalence may construct a working class identity, which links working class subject positions in opposition to a discursively constructed capitalist class. However, the construction of such a subject position requires concerted effort. Alternatively, working class identity might be constructed in alliance with the nation state in opposition to an external other through a discourse of national security (as was witnessed in the aftermath of $9 / 11$ in the United States). Furthermore, they highlight the ways in which we can construct political subjectivity in a multiplicity of ways other than around economic class. In recent decades, the "new social movements" based on gender, ethnicity, sexuality, or environmental degradation, have illustrated that class is not the only channel of social power, nor is it the only foundation upon which resistance to power may be based (p. 159).

The authors also reject the Marxist model of class struggle, where the working class faces off against the capitalist class in an all-or-nothing, epochal struggle, like Godzilla battling Mothra over the fate of Tokyo. As an alternative to the Marxist framework, Laclau and Mouffe offer a pluralist form of political action, where people actively build "chains of equivalence" among different subject positions (p. 170). The creation of counter-hegemonic blocs among subject positions is an active, discursive process. They term this a politics of "radical democracy," where hegemony and 
counter-hegemony are worked out in everyday struggles among a multiplicity of political actors (p. 176). Echoing Gramsci, ideological power does not work as a monolithic system that subjugates the masses in the interests of the capitalist class. Hegemony is always contested; we may only speak of the relative success of a particular hegemonic discourse.

While Laclau and Mouffe work from a Gramscian point of departure, their work has broad resonances with Foucault. The authors contribute to a theory of discourse by focusing on the relationship between discourse, subjectivity and hegemony. As in the work of Foucault, Laclau and Mouffe suggest that an acceptance of social inequality is produced as we incorporate hegemonic discourses into our individual subjectivities. Discourse works on individual social actors while producing hegemonic effects across a multiplicity of social locations. The authors also point to the multiplicity of subject positions, networks of power, and points of resistance beyond the confines of economic class. Laclau and Mouffe also collapse the Marxist distinction between economic base and cultural superstructure by absorbing everything into discourse. However, their conception of discourse may seem so broad that it embraces everything in the social world, leaving nothing outside discourse.

\section{Gender, Ideology and Discourse}

Up to this point, I have traced line across the ideology-discourse continuum. I began with Marx's notion of ideology, moved through the Gramscian model of hegemony, and concluded with a description of the discourse theories of post-structuralism and post-Marxism. I described a movement from a model of ideological closure and domination by one class over its subordinates, to a model of a near-infinite multiplicity of discourses, political subject positions and relations of power. In the remainder of the paper, I examine theories of gender and of "race," as they relate to questions of ideology and discourse. In general, these theories occupy a range of positions on the ideology-discourse continuum. If we imagine a mid-point to this continuum, some of these theories occupy the critical side of this point, while others occupy the post-structural- 
ist side of this point. However, most of the key theorists described here share an interest in exploring the thorny terrain at the centre of the continuum. Furthermore, this body of work has a common interest in decentering the privileged position of economic class.

\section{On the Critical side of the Ideology/Discourse Continuum}

Dorothy Smith $(1990 ; 1999)$ conceives of ideology as a mode of reasoning, or creating knowledge, that abstracts from lived individuals engaged in everyday/everynight social interaction. For example, disciplines like Economics, or Sociology may construct "ideological circles" that form textual realities that are abstracted from the lived, material reality of the work people do to produce and reproduce social life (Smith 1990:172). These abstracted systems of knowledge, which transform human actors into statistics, are part of an apparatus Smith terms the "relations of ruling" that convince us to participate in social systems of oppression and inequality ( $p$. 14). The relations of ruling refers to the ways in which social power works through written texts, such as the rules that govern behaviour in work settings, or the laws that are used to police deviant groups. Smith terms those discourses that are reproduced through texts and work towards ideological closure "T-discourses" (Smith 1999:158). These T-discourses form a dense system that gives voice to the relations of ruling. Ideological T-discourses define the limits of social action and legitimate relations of power. Through the circulation of T-discourses, the relations of ruling found in institutions such as schools and corporations, or in the "Standard North American Family" are reproduced (Smith 1999).

Smith's (1999) writing repeatedly returns to the theme of a revised Marxist materialism, which favors the everyday material activity of individuals as a site for producing knowledge. She posits a "standpoint of women" as a privileged position from which to challenge the relations of ruling (p. 74). For Smith, women collectively occupy a position of subalternity in contemporary societies, which are marked by gendered (as well as class-based) structures of social power. From the material foundation of everyday/everynight action, women's standpoint is equipped to deconstruct the truth 
claims of the relations of ruling, thereby opening up new spaces for political action and resistance. In engaging with textual discourses, Smith describes the need for a forceful re-entry of the social into textual analysis. She writes:

Post-structuralist/postmodernist theorizing of discourse . . . captures the displacement of locally situated subjects precisely in its insistence on the absence of subjects from the determination of meaning and on the self-preferentiality of language and discourse in this new mode. Yet it leaves unanalysed the socially organized practices and relations that objectify, even those visible in discourse itself. . . . Taking women's standpoint, we remember that we, the actual readers/writers/speakers/hearers, who disappear in the relations of intertextuality, are also those who participate, generate, provide the dynamic of the ruling relations (Smith 1999:80).

That is, we should recognize that discourse is a product of social interaction, not only an abstract entity that floats above individual social actors.

Smith brings a necessary focus to the role of living individuals (including social theorists) as active participants in discourse. She is interested in post-structuralism's deconstruction of authoritative discourses and its destabilization of truth claims. At the same time, she is highly critical of post-structuralism's overly discursive conception of the social. Smith's particular model of ideology is also useful. Here, ideology is a system of discourses that constitutes a macro-social set of ruling relations. However, this is produced and reproduced through the micro-social interactions of individuals across a range of social locations.

Smith's notion of the standpoint of women attempts to bridge the post-structuralist destabilization of a universal subject and Marxist realist materialism. She seeks a standpoint epistemology that can destabilize the ideological truth regimes of the relations of ruling, while also producing its own counter-hegemonic truth claims. However, the notion of the standpoint of women risks an essentialized view of gender. While Smith notes the diversity of women's experience, women's standpoint often seems synonymous 
with a standpoint of mothers, wives and caretakers, whose relation to reproductive labor is their defining characteristic. Similarly, Smith describes a male social science that is inherently abstract from social reality, while women's standpoint is rooted in processes of social reproduction. This does risk reproducing a Cartesian dichotomy where men occupy an abstract, intellectual social space, while women occupy a material, bodily realm. Here, Smith risks valorizing the latter in place of the former.

\section{On the Post . . Side of the Ideology/Discourse Continuum}

Smith generally inhabits the critical theory side of the ideology-discourse continuum, while also engaging with the insights of post-structuralism. However, feminist engagements with issues of discourse, ideology and social power also occur on the post-structuralist side of the continuum. For example, Donna Haraway inhabits a tension between critical theories of ideology and post-structural theories of discourse, while arguing against a class-centered notion of social power and political agency.

Haraway's (1991) “Cyborg Manifesto," which alludes to Marx's Communist Manifesto, poses a challenge to narratives of economic class that have been central to critical theories of power, politics and resistance. In this essay and elsewhere, Haraway (1991; 2004 [1992]) focuses on the many ways in which the social world can no longer be understood according to a binary logic of class (ruling class vs. working class), or of gender (men vs. women). Rather, if we experience the world through the lens of class or gender, it is because we pick up dominant discourses of gender and class, make them our own, and express them through our social relations with others. As Haraway (1997) writes:

Gender is always a relationship, not a preformed category of beings or a possession that one can have. Gender does not pertain more to women than to men. Gender is the relation between variously constituted categories of men and women . . . differentiated by nation, generation, class, lineage, color, and much else (p. 28). 
Haraway characterizes the "amodern" social world by the growing permeability of boundaries between humans and animals, society and nature, and the organic and the technological (Haraway 2004 [1992]:77). The result is that the amodern subject position is always a "cyborg" subject position. The cyborg is a recurring, often monstrous, figure of science fiction that is part human and part machine (Haraway 1991:148). For Haraway, it is a suitable metaphor for our current experience of subjectivity. We are no longer simply members of a class, a gender, a nation, or an ethnic group. Rather, we are hybrid beings, composed of multiple identity positions that overlap and intersect. She writes, "So my cyborg myth is about transgressed boundaries, potent fusions, and dangerous possibilities which progressive people might explore as one part of needed political work" (p. 154). Her use of an often monstrous trope suggests that a cyborg politics must also engage with that which appears alien and hostile upon first glance; it challenges us to overcome a binary politics of "good versus evil."

Related to this is Haraway's notion of the "informatics of domination" (p. 161; also see Gane and Haraway 2006). This is her expression of a rather Foucaultian conception of power, wherein social power is not a top-down flow from elites to masses, or an objective thing, but a property of social relations. Like Foucault, Haraway sees power operating in a dense network throughout the everyday social world. Here, the creation and reproduction of gendered, racialized and class based systems of power continue to have relevance, but Haraway wants us to rethink the ways in which these systems of power are intertwined and joined by other power relations built around sexuality, nationality, species, and so on.

Also echoing Foucault, the exercise of power always implies the possibility of resistance. While the informatics of domination permeates all social relations, these relations “aren't all powerful, they're interrupted in a million ways ... one minute they look like they control the entire planet, the next minute they look like a house of cards" (Gane and Haraway 2006:151). Echoing Laclau and Mouffe's notion of radical democracy, if there is a collective political actor it is not Marx's working class. Rather, it is a cyborg entity, made up of a multiplicity of partially connected actors. 
Discourses of gender, class, "race" and sexuality are the tissues that potentially bring together members of this cyborg political subject. What is unique about Haraway's vision and distinguishes her from both other feminist and post-structuralist theorists, is that both the cyborg figure and the informatics of domination do not consist only of human actors. Haraway's theory of power, domination and political subjectivity expands to include humans, animals, machines, myths and science fictions in its collection of parts.

Haraway takes up post-structuralist and post-Marxist themes in her deconstruction of the grand narratives of class domination and revolution that characterize critical theories of ideology. A post-structuralist influence is also evident in her uneasiness with a universal female subject within feminist theory and her desire to view gender as a social process, rather than a preformed essence.

However, Haraway is distinct from other post-structuralist influenced writers in her insistence on the materiality of a social world that becomes intelligible through discourse. She is perhaps not as materialist in orientation as Smith is, but neither does she inhabit a theoretical world of pure simulation and textuality. Furthermore, both Haraway and Smith display a willingness to navigate the messy terrain between critical theories of ideology, and post-structuralist and post-Marxist theories of discourse.

From this perspective, it appears that individual and collective social actors consent to participate in systems of gendered and class-based social inequality through their engagement with a multitude of discourses about gender, class, "race," sexuality, or nature. These discourses circulate throughout everyday life: in the media, schools, or the family. This approach to the question of our participation in systems of domination and inequality pays attention to the insights of both critical theory and post-structuralism.

\section{'Race' and Ethnicity, Ideology and Discourse}

Critical theories of "race" and ethnicity also point to a lacuna in critical theories of ideology. Whereas gender theory refocuses our attention on the way that ideological discourse may reproduce relations of inequality between men and women, critical "race" 
theories bring racialized networks of power into view. Here, we see how the consent of subjects of inequitable relations of power is secured through discourses of racialization, which circulate at both micro-social and macro-social levels.

\section{On the Critical Side of the Ideology/Discourse Continuum}

Franz Fanon (2004 [1963]) takes up many of the same themes found in Gramsci's work. In his analysis of colonialism, Fanon focuses on issues of hegemony, the role of Third World intellectuals in providing direction to revolutionary moments, and the difficulty of applying Marxist theoretical schemes to class politics in the colonized world. One of Fanon's (2004 [1963]) central claims is that colonialism constructs a "compartmentalized world" of colonist and colonized, where "race" is just as significant a social force as class (p. 5). Within this compartmentalized world, the colonized are subject to a hegemony that is material/economic as well as cultural and psychological. Fanon (2004 [1963]) writes:

Looking at the immediacies of the colonial context, it is clear that what divides this world is first and foremost what species, what race one belongs to. In the colonies the economic infrastructure is also a superstructure. The cause is effect: You are rich because you are white, you are white because you are rich (p. 5).

Colonized peoples see themselves through the eyes of the colonizer, as the marginalized other to a valorized European culture. Thus, colonialism functions through economic and political domination, as well as through cultural hegemony.

According to Fanon (and foreshadowing Marcuse), the members of colonized societies who are admitted to the bourgeoisie and the working class are too easily swayed by the concessions of colonialism to effectively form a collective political actor. Fanon writes, "In the capitalist countries, the proletariat has nothing to lose and possibly everything to gain. In the colonized countries, the proletariat has everything to lose. It represents in fact that fraction of the colonized who are indispensable for running the colonial machine" (p. 64). Instead, the lumpenproletariat of Third World 
villages - the most marginalized members of colonial society--becomes the most promising historical class actor. With the guidance of subaltern intellectuals, the subaltern classes can launch a dual revolution of violence and cultural rejuvenation against the colonizing class. For Fanon, violence is both a psychological and social necessity. Violence is the only tool that is capable of driving out the colonizer. At the same time, violence works as a form of social therapy, a physical act of rejection of colonial cultural hegemony.

Fanon's main strength is a radical re-reading of Marx, which illuminates how ideologies of racialization work within a distinct form of the capitalist mode of production. For example, he illustrates how the interests of colonized members of the proletariat and bourgeoisie are articulated to the colonial social order. At the same time, Fanon's adherence to Marxist class categories is a limitation, even where a racialized lumpenproletariat displaces the (White) proletariat as a historical class actor. Fanon's valorization of violence as a force for social change is also questionable, when one considers the failure of violent revolution to create equitable and just socialist societies in the twentieth century. Nevertheless, as Parry (2004) argues, Fanon is worth drawing upon for his insistence that anti-colonial politics cannot be limited to the realm of culture. Rather, resistance to racialized networks of power requires a praxis that combines the deconstruction of hegemony with concrete political action.

Similarly, Stuart Hall draws upon Gramscian theory as a tool for bridging cultural analysis and the economic analysis of traditional Marxist theory. In "Race, Articulation, and Societies Structured in Dominance," Hall (1980; also see Hall, 1996a) explores the relevance of Gramsci for critical "race" theory. His argument is dialectical in form. First, he describes a Marxist approach to "race," wherein racism is rooted in economic structure. Here, racial inequality is a cultural reflection of the economic base of society. Racializing ideologies work to justify a system of economic inequality that is beneficial for capital, in terms of providing a supply of cheap, disposable labor.

This position is contrasted with its opposite, a cultural theory of "race," in which "race" is seen as important in itself for struc- 
turing social relations. Here, racialized networks of power appear to have no reference to the political economy of capitalism. From here, Hall invokes Gramsci to synthesize the opposing positions. For him, the Gramscian position illuminates how racist ideologies and social practices are articulated to systems of economic stratification in distinct ways in specific historical and social locations. He writes:

One must start, then, from the concrete historical 'work' which racism accomplishes under specific historical conditions - as a set of economic, political and ideological practices ... Though the economic aspects are critical, as a way of beginning, this form of hegemony cannot be understood as operating purely through economic coercion (Hall 1980:338).

We cannot assume the specific forms of articulation between racializing discourse and material inequality a priori, but must attend to how people work to create and resist these articulations in specific social settings.

While Hall is useful for conceptualizing the interconnections between class and "race" in the cultural and economic spheres, there is a sense here that class is a more objective form of social identity than "race." That is, Hall seems to suggest a Marxist notion of classes as a priori historical actors, while "races" appear as ideological social constructions.

\section{On the Post . . Side of the Ideology/Discourse Continuu}

The work of Edward Said provides a point of entry into a more cultural approach to questions of discourse, racialization and power. In Orientatlism, Said (1979) draws on Foucauldian notions of discourse and power/knowledge to produce a genealogy of "Orientalism" as an academic discipline (p. 6). Orientalism refers to systems of constructing knowledge about--and producing - "the Orient" as a discursive object of colonialism and governance (p. 177). While Said is careful to note that we should understand the power-effects produced by Orientalist discourse as working in conjunction with the political institutions of colonialism, the bulk of his analysis 
provides deep readings of Orientalist texts. Echoing Fanon, Said notes that Orientalist discourse produces an essentially divided social reality, split between the Occidental self and the Oriental other. Hegemonic discourses of Orientalism work to legitimate Western cultural, political and economic dominance over the Middle East and North Africa.

Said's work is useful for illuminating how cultural discourses construct an Orient that can be subjected to Western political and economic domination. Said echoes Fanon in his description of a fundamentally divided world. However, Said departs from Fanon in his analytical emphasis on the cultural realm as the place where social power is expressed. Unlike Fanon, he backgrounds an analysis of economic structures and state coercion as primary forms of social control, though he does allude to their importance as "stabilizing influences" in the process of colonization (p. 201).

However, Ahmad (1992) argues that Said's notion of an Orientalist discourse that spans ancient Greek writing to the present is fundamentally un-Foucauldian in its totalizing, ahistorical form. Said is also criticized for not including other voices of resistance, for not giving voice to the patterned silences in Orientalist discourse. The only deconstructive voice is Said's. He does not account for the ways in which subjects of this dominant discourse have received, negotiated, or rejected it. We could extend this critique to a significant portion of discourse theory.

In Yearning, bell hooks (1990) explores the intersections of "race," class and gender in social inequality and counter-hegemonic politics. Through a series of essays, she provides a wide-ranging discussion of postmodernity, the discursive representation of Black identity, and strategies for resistance to racialized systems of power. Like Said, she also engages in a critical reading of cultural texts, though she is primarily interested in the production of Blackness and gender in books and film. For hooks, the vision of difference embodied in post-structuralism, which undermines the notion of a unitary historical class actor, is problematic when it displaces notions of "oppression, exploitation, and domination" from its analysis (hooks 1990:51-52, emphasis in original). For her, we should not lose sight of racialized and gendered structures 
of privilege and oppression, which are both material and cultural. Thus, a counter-hegemonic politics that takes up the challenge of post-structuralism requires constructing linkages across multiple sites of subalternity.

For hooks (1990), the notion of "yearning" provides a foundation for a counter-hegemonic political standpoint that incorporates "race," gender and class as dimensions of social power (p. 27). She describes yearning as "a common psychological state shared by many of us . . . Specifically, in relation to the post-modernist deconstruction of 'master' narratives, the yearning that wells in the hearts and minds of those whom such narratives have silenced is the longing for critical voice" (p. 27). hooks sees "marginality" as an important location for the production of knowledge and for engaging in political resistance to power (p. 149). She writes:

Understanding marginality as position and place of resistance is crucial for oppressed, exploited, colonized people. If we only view the margin as sign marking the despair, a deep nihilism penetrates in a destructive way the very ground of our being. ... I am not trying to romantically re-inscribe the notion of that space of marginality where the oppressed live apart from their oppressors as 'pure.' I want to say that these margins have been both sites of repression and sites of resistance" (hooks 1990:150-151).

Similar to Smith's standpoint of women, hooks advocates a politics that is grounded in the experience of marginality and subalternity. This experiential position facilitates the construction of a counterhegemonic knowledge that can undermine the master narratives of class, "race," and gender without abdicating the ability to make truth claims.

Like Smith and Haraway, theorists like Hall and hooks attempt to navigate the tensions between critical theories of ideology and the post-structuralist and post-Marxist focus on discourse. This work moves us beyond a model of class as the sole foundation of ideological power and political resistance. It also adopts a broader conception of social power than posited by Marxist theory. However, these theorists avoid a conception of power that is so diffused that it becomes meaningless to talk about class, gender and 
racialization as structures of power that inform social interaction at the everyday level. Here, consent to systems of domination is produced as people adopt the discourses of class, "race" and gender that circulate throughout the media, the state and the education system. These discourses make our ongoing participation in existing systems of political and economic inequality seem more feasible than political action directed at radical social change.

\section{Conclusion}

Through this theoretical overview, I have traced a route through a map of theories of ideology, hegemony and discourse (recall Figure 1). These key theorists provide a variety of explanations for the ways in which ideology and discourse function to convince people to accept systems of social inequality as acceptable and immune from social transformation. In explaining why people consent to unequal relations of social power, they also illuminate possibilities for resistance to ideological power and for social change.

In the first part of this paper, I described the movement from Marxist theories of ideology, through Gramscian hegemony theory post-structuralist and post-Marxist theories of discourse. This path takes us from theories of ideological power as relatively closed, unidirectional and monolithic to a model of discursive power as open, contested and microsocial. Second, I examined bodies of theory that deny economic class its status as the foundational site of ideological power and political resistance. Through critical theories of "race" and gender, we see how ideological discourse works to construct racialized and gendered networks of power.

The first part of this paper follows in the tradition of earlier reviews of Marxism, critical theory and post-structuralism (Agger 1998; Best and Kellner 1991; Eagleton 1991). In contrast to these reviews, I have focused specifically on how these bodies of theory approach the problematic of the relationship between the production of social knowledge and the reproduction of inequitable systems of social power. At the same time, I have attempted to broaden the scope of theoretical dialogue to include critical theories of gender and "race" as important contributions to our understanding of how 


\begin{tabular}{|c|c|c|c|}
\hline 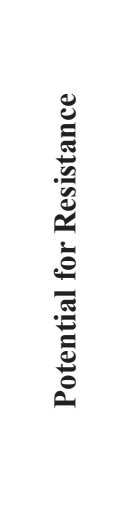 & 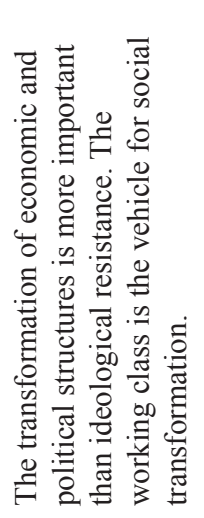 & 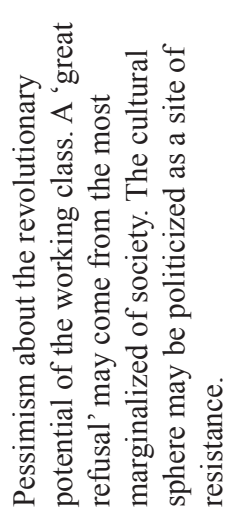 & 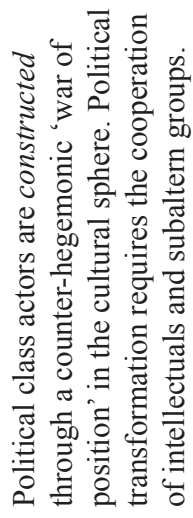 \\
\hline 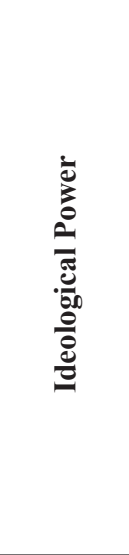 & 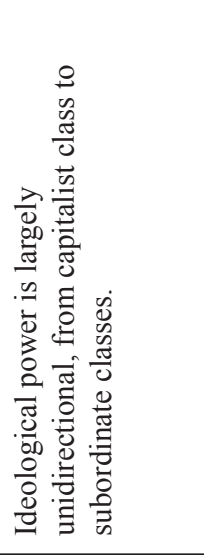 & 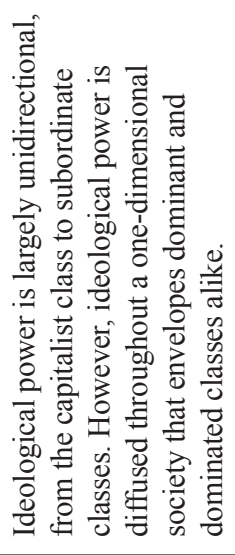 & 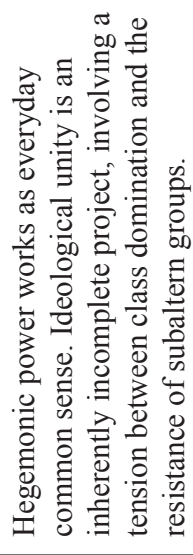 \\
\hline 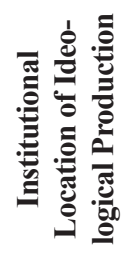 & 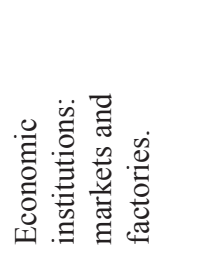 & 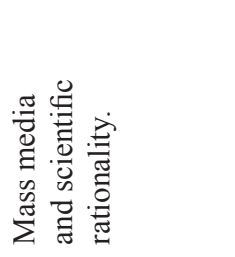 & 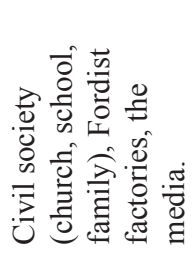 \\
\hline & 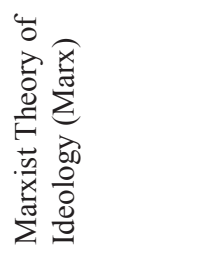 & 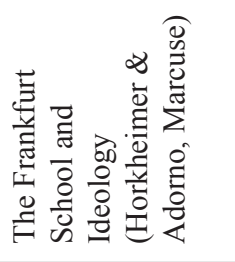 & 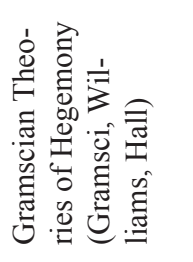 \\
\hline
\end{tabular}




\begin{tabular}{|c|c|c|}
\hline 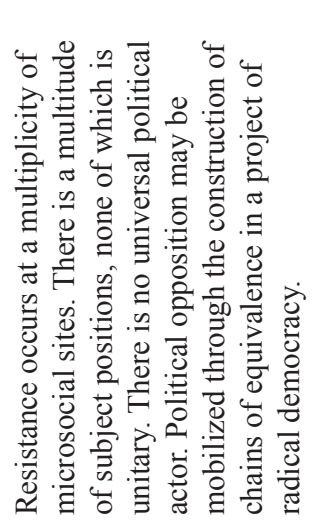 & 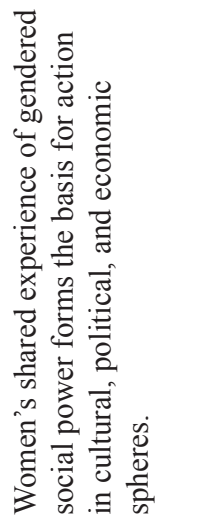 & 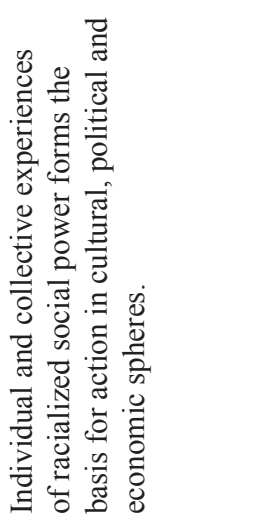 \\
\hline 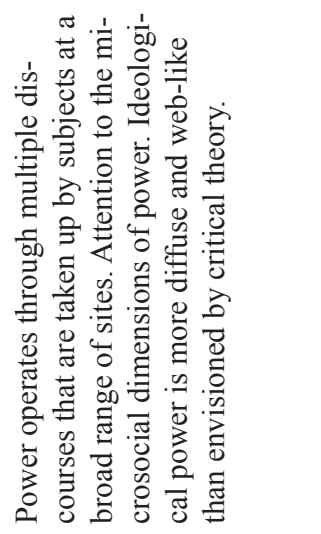 & 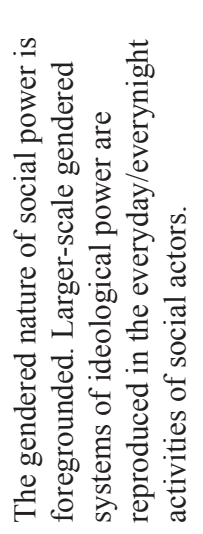 & 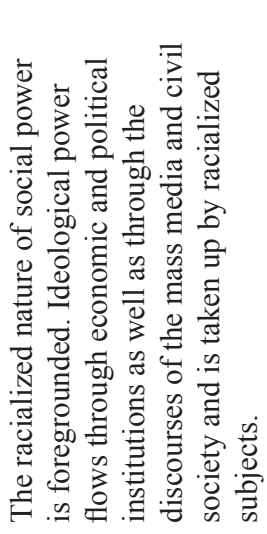 \\
\hline 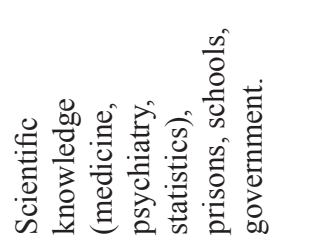 & 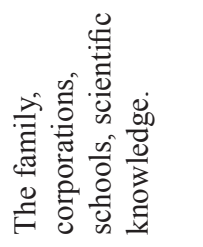 & 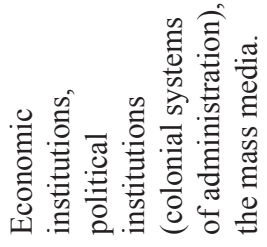 \\
\hline 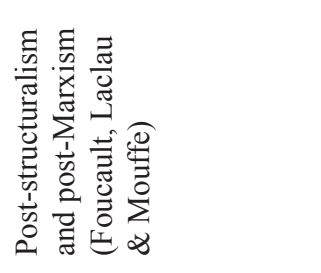 & 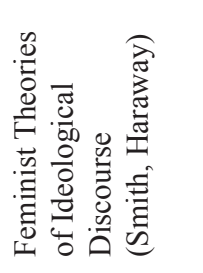 & 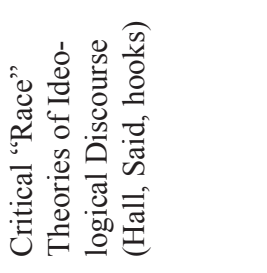 \\
\hline
\end{tabular}


culture and knowledge are mobilized to reproduce social privilege and inequality. As such, this paper differs from earlier reviews by going beyond calls for a rapprochement between critical theory and post-structuralism.

Table 1 (see pages 220-221) summarizes the key bodies of theory reviewed here and compares them along three dimensions: the institutional sites of ideological power, the character of ideological power, and the vision offered for resistance to ideological power. Here, we see how each of these theoretical approaches envisions the social institutions that produce consent to power, the nature of consent to power, and the possible limitations to consent. Marxist and critical models focus on how cultural production inculcates consent among the working classes in a largely unidirectional way. By contrast, post-structuralism focuses on how ideological power is neither unidirectional nor homogenous. Instead, consent and resistance are produced through a multitude of discourses that circulate throughout the social, without the direction of particular elites.

However, the ongoing work of theorists of gender and "race" - Hall, Smith, hooks and Haraway — offers a more complex understanding of how our consent to power is produced within contemporary capitalist societies. There are three reasons that I make this claim. First, though there are important distinctions between these theorists, all of them attempt to inhabit the muddled terrain between the extreme poles of ideology theory and discourse theory. These authors eschew the notion that social relationships in the economic base determine the content of the cultural superstructure. However, there is also typically an aversion to a conception of the social as entirely discursive. Second, while these theories engage with Foucault's emphasis on the microsocial dimensions of discursive power, they do not let go of the notion that there are persistent patterns of macrosocial power. Third, these theorists also pick up post-structuralism's destabilization of class as the main force for structuring social power. However, they avoid a conception of political subjectivity that is so open as to make collective political action difficult to envision.

Through this work, we see how consent to multiple intersecting networks of power occurs because we adopt the discourses that circulate throughout civil society (the media, schools, family). As 
we take up ideological discourses, we become gendered and racialized subjects. Through the everyday mundane nature of ideology, we come to accept inequities of class, gender, and ethnicity as immune to radical transformation. However, ideological closure is never completely achieved. As people actively forge political connections among different subject positions, they illuminate the limits of consent and disrupt it. Of the key theorists reviewed here, it is the work of Hall, Smith, hooks and Haraway that present the most useful directions for moving forward as we continue to think about the relationships between culture and economy, knowledge and power, and domination and resistance.

If this model of power, domination, and consent is correct, there are also important implications for theory and political practice. In this model, power is discursive, while having material effects. It flows throughout daily life in multiple directions. As such, it is untenable to envision a Marxist style of revolution, which can ultimately overcome power. Instead, we are better off directing theory and practice at destabilizing our consent to these power relations. Social theory might help produce the kind of reflexivity that encourages us to better monitor and manage relations of power. This leaves us with the prospect of an endless project of challenging and minimizing the harmful effects of power relations, through practices like radical democracy or cyborg politics.

\section{References}

Agger, Ben. 1998. Critical Social Theories: An Introduction. Oxford: Westview Press.

Ahmad, Aijaz. 1992. "Orientalism and After.” Pp. 159-219 in In Theory: Classes, Nations, Literatures. London: Verso.

Benjamin, Walter. 1968 [1936]. "The Work of Art in the Age of Mechanical Reproduction." Pp. 217-251 in Walter Benjamin: Illuminations, edited by H. Arendt. New York: Schocken Books.

Best, Steven and Douglas Kellner. 1991. Postmodern Theory: Critical Interrogations. New York: The Guildford Press.

Eagleton, Terry. 1991. Ideology: An Introduction. London: Verso.

Fanon, Frantz. 2004 [1963]. The Wretched of the Earth. Translated by R. Philcox. New York: Grove Press. 
Femia, Joseph. 1975. "Hegemony and Consciousness in the Thought of Antonio Gramsci." Political Studies 23:29-48.

Foucault, Michel. 1978. The History of Sexuality Volume I: An Introduction. Translated by R. Hurley. New York: Vintage Books.

—. 1980a. "Truth and Power." Pp. 109-133 in Power/Knowledge: Selected Interviews and Other Writings 1972-1977, edited by C. Gordon. New York: Pantheon Books.

. 1980b. "Two Lectures." Pp. 78-108 in Power/Knowledge: Selected Interviews and Other Writings 1972-1977, edited by C. Gordon. New York: Pantheon Books.

— 2000 [1994]a. "The Subject and Power." Pp. 326-348 in Power: Essential Works of Foucault 1954-1984, Volume 3, edited by J. Faubion. New York: The New Press.

—. 2000 [1994]b. "Truth and Juridical Forms." Pp. 1-89 in Power: Essential Works of Foucault 1954-1984, Volume 3, edited by J. Faubion. New York: The New Press.

—. 2003. "Society Must be Defended": Lectures at the College de France, 1975-1976, edited by M. Bertani and A. Fontana. Translated by D. Macey. New York: Picador.

Gane, Nicholas and Donna Haraway. 2006. "When We Have Never Been Human, What Is to Be Done? Interview with Donna Haraway." Theory, Culture \& Society 23:135-158.

Gramsci, Antonio. 1971. Selections from the Prison Notebooks of Antonio Gramsci. Translated by Q. Hoare and G. N. Smith. New York: International Publishers.

— 1992. Prison Notebooks: Volume I. Translated by J. A. Buttigieg. New York: Columbia University Press.

—. 1996. Prison Notebooks: Volume II. Translated by J. A. Buttigieg. New York: Columbia University Press.

Hall, Stuart. 1980. "Race, Articulation and Societies Structured in Dominance." Pp. 305-345 in Sociological Theories: Race and Colonialism. Paris: UNESCO.

- 1992. "Cultural Studies and its Theoretical Legacies." Pp. 277-294 in Cultural Studies, edited by L. Grossberg, C. Nelson, and P. A. Treichler. New York: Routledge.

- 1996a. "Gramsci's Relevance for the Study of Race and Ethnicity." Pp. 411-440 in Stuart Hall: critical dialogues in cultural studies, edited by S. Hall, D. Morley, and K.H. Chen. London: Routledge. . 1996b. "The Problem of Ideology: Marxism without Guarantees." Pp. 57-85 in Marx 100 Years On, edited by B. Matthews. London: Lawrence \& Wishart. 
Haraway, Donna Jeanne. 1991. "A Cyborg Manifesto: Science, Technology, and Socialist-Feminism in the Late Twentieth Century." Pp. 149-182 in Simians, Cyborgs, and Women: The Reinvention of Nature. New York: Routledge.

Haraway, Donna. 1997.Modest_Witness@Second_Millennium: FamaleMan_Meets_OncoMouse. New York: Routledge.

_ 2004 [1992]. "The Promises of Monsters: A Regenerative Politics for Inappropriate/d Others." Pp. 63-124 in The Haraway Reader. New York: Routledge.

Hartsock, Nancy. 1990. "Foucault on Power: A Theory for Women?" Pp. 157-175 in Feminism/Postmodernism, edited by L. Nicholson. New York: Routledge.

hooks, bell. 1990. Yearning: Race, Gender, and Cultural Politics. Boston: South End Press.

Horkheimer, Max and Theodor Adorno. 2002. Dialectic of Enlightenment: Philosophical Fragments. Translated by E. Jephcott. Stanford: Stanford University Press.

Laclau, Ernesto and Chantal Mouffe. 1985. Hegemony and Socialist Strategy: Towards a Radical Democratic Politics. London: Verso.

Marcuse, Herbert. 1991 [1964]. One-Dimensional Man: Studies in the Ideology of Advanced Industrial Society. Boston: Beacon Press.

Marx, Karl. 1977. Capital: A Critique of Political Economy (Volume 1). Translated by B. Fowkes. New York: Vintage Books.

Marx, Karl and Friedrich Engels. 1989. "Excerpts from The German Ideology." Pp. 246-261 in Basic Writings on Politics and Philosophy, edited by L. S. Feuer. New York: Anchor Books.

Parry, Benita. 2004. "Problems in Current Theories of Colonial Discourse." in Postcolonial Studies: A Materialist Critique. London: Routledge.

Purvis, Trevor and Alan Hunt. 1993. "Discourse, Ideology, Discourse, Ideology, Discourse, Ideology . . ." British Journal of Sociology 44:473-499.

Said, Edward W. 1979. Orientalism. New York: Vintage Books.

Smith, Dorothy E. 1990. The Conceptual Practices of Power: A Feminist Sociology of Knowledge. Boston: Northeastern University Press.

—. 1999. Writing the Social: Critique, Theory, and Investigations. Toronto: University of Toronto Press.

Williams, Raymond. 1977. Marxism and Literature. New York: Oxford University Press. 